Hilgers, Tina. 2008. "Causes and Consequences of Political Clientelism: Mexico's PRD in Comparative Perspective." Latin American Politics and Society 50(4): 123-153.

\title{
Causes and Consequences of Political Clientelism: Mexico's PRD in Comparative Perspective
}

\begin{abstract}
PRD politicians and officials widely use clientelism to structure their relationships with citizens. This is not only due to the entrenchment of clientelism in Mexican politics, or to high rates of poverty and inequality, but also to the limited institutionalization of democratic rules inside the party. The latter stems largely from the party's electoral strategy in its formative years and has resulted in uncontrolled factional battles that play out through clientelism. The Brazilian PT faced external and internal conditions quite similar to those of the PRD, but its early focus on organization building and policy change allowed it to avoid clientelism to a greater degree. The analysis problematizes the trend of using minimalist definitions that assume clientelism to be non-democratic because these result in conceptual stretching and decreased explanatory power.
\end{abstract}

The Partido de la Revolución Democrática (Democratic Revolutionary Party, PRD) is Mexico's largest left-wing political party. ${ }^{\mathrm{i}}$ It was established in 1989 in opposition to the Partido Revolucionario Institucional (Institutional Revolutionary Party, PRI) that had dominated the country's politics since its inception in 1929. In some ways the PRD has been extraordinarily successful. In others, it has been a great disappointment. Candidates for the PRD and the electoral coalition that preceded it have twice come close to winning presidential elections, most recently in 2006, when the 
candidate came within less than $1 \%$ of his opponent. Moreover, the party was instrumental to Mexico's democratic transition and it has given hope for political and economic betterment to millions of people. At the same time, the PRD has been handicapped by factionalism, personalism, and clientelism, losing many supporters who became disillusioned by its practices. Why have PRD politicians come to use clientelism despite their efforts to avoid the methods of the PRI?

A series of external factors - poverty, the lengthy history of clientelism in Mexican politics, the PRI's extensive use of this method to ensure political stability, as well as the PRD founders' proficiency in these methods - are important in answering this question. However, these did not guarantee that the new party would be marked by clientelism to the degree that it has. Rather, a succession of internal events, among which the party's strategy for bringing about a transition to democracy stands out, have a more direct causal relationship with the outcome of clientelism

The PRD was established from a wide front of left-wing parties, social movements, and individuals, with diverse ideological visions. Coordinating these currents under one organizational roof could have taken various forms based on individual direct participation, ideological or programmatic groups, centralized or decentralized power, and so on. However, the emergence of one predominant leader, Cuauhtémoc Cárdenas, and the primacy of his political strategy set the party on a path of personalistic factions and centralized power, despite the best intentions not to replicate these characteristics of the PRI. As a result of Cárdenas's desire to oust the PRI from power, to do so in the electoral arena, and to do it as soon as possible, the PRD focused resources on elections. The resources - including time - that would have been necessary 
for institutionalizing party rules and regulations to ensure internal cohesion and democratic procedures were not available. As a result, leadership and alliances were personalized and factions battled for power. When the PRD began to win local and state governments, these tendencies spilled into its administrations and played out as clientelistic relationships with citizens.

Thus, big events - such as the Mexican tradition of clientelism - are important in defining particular paths, but smaller events occurring at key moments may have an equally significant impact (see Pierson 2000). According to path dependence, history matters in a very particular way because the outcomes in one setting can be quite different from those in another setting based on the timing and sequence of events. The primacy of an electoral strategy so early in the life of the PRD was decisive for factionalism and, eventually, clientelism in the party. As we will see, the Brazilian Partido dos Trabalhadores (PT) shared quite a lot of the PRD's characteristics and external influencing factors at its formation, but chose an organization-building strategy. The PT has been able to rely less on clientelism and more on community building, only beginning to encounter serious problems of patronage and corruption (mislabeled as clientelism by a number of analysts) much later in its life, once it focused on winning national elections.

Analyzing clientelism in the PRD, and attempting to uncover instances thereof in the PT, also leads to an interesting finding regarding clientelism as a concept. The study of this phenomenon has enjoyed a recent revival among researchers trying to understand why democratization has not always been as successful as anticipated by the scholarly and political communities. Unfortunately, many of these researchers take for granted that 
clientelism, having been a key tool for maintaining economic and political stability under non-democratic regimes, is necessarily non-democratic in itself. The earlier literature on clientelism was more ambiguous on this point, including a vigorous debate on the value of clientelism for the client. The significance of this discussion continues to be vindicated by the experiences of those involved in clientelism. A priori viewing clientelism as a non-democratic practice seems to have brought about a conflicting result. While there is a narrower interpretation of the phenomenon with respect to democracy than is warranted empirically, we also see conceptual stretching, as a number of practices identified as non-democratic have all come to be labeled as clientelism. An example of stretching can be seen in the growing reports of supposed clientelism in the PT, which more properly refer to patronage, vote-buying and corruption. The significance of clientelism's ambiguity regarding democracy is apparent in an examination of PRD clients' experiences, which range from exploitation to participatory community building.

\section{Defining Clientelism}

For the purposes of this article, I will rely on Roniger's (1990) discussion of clientelism as a guiding line. Roniger (1990) provides a definition of clientelism that covers the essential aspects traditionally considered important. He sees clientelist relations as dyadic (two-person), voluntary, reciprocal, face-to-face links between individuals of unequal status who exchange non-comparable goods and services in a relationship that may involve affectivity, is based on norms of reciprocity and obligation, and plays out over time and across a broad series of interactions (2-4). They are relationships in which a person of social status (the patron) and a second person of low status (the client) agree to exchange goods and services (usually resources such as 
housing, food, medical supplies, legal advice, and so on, for political support) to mutual benefit. The durability of the relationship depends on its benefits outweighing its costs. In a discussion of his definition, Roniger $(1990,4)$ points to the contradiction between, on the one hand, the possibility, and often reality, of coercion and exploitation, and, on the other hand, the language and ideology of voluntariness and mutual obligations. This is not a recent debate - much ink has been spilled over the tensions in clientelism in the past. For example, the resources controlled and exchanged by each party are sometimes labeled as "unequal" and sometimes as non-comparable. Legg (1975) argued that inequality implies a value differential: the value of the resources controlled by the powerful patron outweighs that of the resources controlled by the lowstatus client; and the patron benefits more from the transaction because his higher value resources give him a better negotiating position. However, Legg felt that value is subjective - it depends on the significance of the resources to the parties involved - so that different resources should be described in terms of non-comparability, rather than inequality. The resources exchanged do not have to be equivalent, but have to fulfill mutual expectations (4-8, 13-15).

Similarly, Gouldner (1977) wrote that clientelism has too often been considered exploitative because one party is used unfairly by another. He argued that this is a mistake because the transactions are based on a "principle of reciprocity", a moral code that creates the obligation to return good deeds. Someone who has given goods or services deserves to receive benefits in return (35). Importantly, according to Gouldner, these reciprocal exchanges do not depend on social roles in which duties or rights are attached to particular status positions. They are obligations based on others' past actions. 
Flynn (1975), on the other hand, argued that all discussions of clientelism's internal characteristics were missing the big picture - that clientelism is a mechanism of elite control over the masses. Others maintained that clientelist relations thwart the emergence of collective organization, limit the internal democracy of civil society, obstruct efficient production and resource allocation, and generally inhibit political freedom and participation while perpetuating economic inequality (Flynn 1975, Putnam 1993, and Kurer 1993; see also Kitschelt 2000). Thus, despite the reciprocity and mutual benefit that have been defining aspects of clientelism in the past, the literature has generally given it a negative connotation. It tends to be seen as a relation of domination in which powerful patrons - politicians or landlords - benefit more than their poor clients (see, for example, Singelmann 1981, Brusco, Nazareno, and Stokes 2002). Because analysts, as Hellman (1994b) argues, have considered autonomous and ideologically motivated political participation as more important than the fulfillment of basic needs, they have tended to judge the effects of clientelism negatively. There are, of course, exceptions to this rule, particularly in the ranks of sociologists and anthropologists (see, for example, Fernández-Kelly and Shefner, eds., 2006).

Fox (1994) attempted to bring some clarity to the question of who benefits by dividing clientelism into two categories. He described "authoritarian clientelism" as a relationship marked by asymmetrical power, in which the subordination of clients is maintained through coercion - either threatened or real (153). To this, he counterposed "semiclientelism", where elites do not have the capacity to enforce subordination, but attempt to ensure compliance by threatening benefit removal (157-158). 
Most recent definitions come from perspectives driven by economic theory and attempt to modernize the concept of clientelism by removing the elements that their authors associate with traditional landlord-peasant links. They eliminate affectivity, faceto-face contact, long-term duration, non-comparability, reciprocity, and dispersion of the relationship across a variety of exchanges, in order to do away with the personal and emotional attachments that - claim the authors - do not reflect modern political reality (Piattoni 2001, 9-11). Instead, they pare the definition down to a rational, interest maximizing exchange of votes or other forms of political support for benefits (Piattoni 2001, 4, 11) in which participants gain confidence with repetition (Kitschelt and Wilkinson 2007, 7-9). They counterpose this to situations in which political parties win votes based on the perceived merits of the universalistic policies and programs they enact and propose. That is, clientelism is placed on the non-democratic end and programmatic platforms on the democratic end of a spectrum of vote-gathering methods.

The discussion on how best to describe clientelism is not advanced by removing all ambiguity regarding democratic practices from the definition. As we will see in the discussion of PRD clients' perspectives, removing these elements does not mean that they cease to exist in the experience of clientelism on the ground (see also Gay 1999; Hellman 1994b) and the tension between positive and negative processes runs to the very heart of clientelism, so that recent definitions do not convey its full meaning. Because clientelism tends to involve voluntary participation and a series of exchanges that allow clients to hold patrons accountable, it can be quite a democratic process. In fact, it is often the only mechanism of political accountability available to marginalized sectors of the population - in non-democratic as well as in democratic systems (Gay 1999). 
Finally, describing clientelism as a simple exchange of support for benefits does not distinguish it from patronage, vote buying, or pork-barreling. Patronage is the distribution of public sector jobs to loyal supporters who help the candidate or party by collecting information on voters and generating votes - frequently through clientelism (Remmer 2007). The recipients of patronage are, thus, often the middlemen (or brokers) in clientelistic relationships. It has been said that such brokers are sometime patrons and sometime clients, depending on with whom they are dealing (see, for example, Powell 1977), but this attempt to conceptually replicate the relationship that exists at the bottom of a hierarchical unit up into its higher ranks confuses the definition. In vote buying, an individual citizen is given money, goods, or services shortly (hours or days) prior to an election in exchange for his or her vote. Unlike clientelism, this is a one-shot, direct exchange, in which the participants have no particular characteristics other than that the recipient is a voter (Schaffer 2007). Pork-barrel politics refers to electoralist policymaking, where politicians promote distributive policies whose benefits are concentrated in their district, but whose cost is carried by the electorate at large (Ricci 2003). Porkbarreling is not a personal relationship and does not require the individual pressure to perform that is an integral element of clientelism. Although patronage, vote buying and pork-barreling often occur in conjunction with clientelism, they describe a variety of activities and should remain conceptually differentiated. Such definitional rigour facilitates the accurate comparison of phenomena across cases, such as the PRD and the PT.

\section{The Initial Causes of Perredista Clientelism}


Clientelism had been used in Mexico since colonization as a mechanism of social organization and control, but was a diffuse system until the PRI established the presidency as the central node in a network superimposed on the old relationships (Roniger 1990). Political interest groups (camarillas) organized networks in which actors endorsed successful figures - reaching all the way up to the president - and moved up through the ranks of public office with their mentors, in an exchange of positions or influence for loyalty (Centeno 1997, 146). Rewards were also distributed through corporatist peasant, labour, and popular sectors in return for well-structured support from the rank and file (Singelmann 1981, 160). Social dissent was avoided through clientelist cooptation - those willing to play by the PRI's rules received preferential access to public resources (Hellman 1988).

This system functioned very well for the PRI while the state-led Mexican economy was in expansion in the post World War II era. However, economic modernization created an educated middle class that grew restless under the PRI's heavy handed regime. Subsequently, a series of economic crises restricted state resources, making it difficult for the PRI to feed its traditional clientelist networks (see Hellman 1994a, Collier and Collier 2002, Middlebrook 1995). From the late 1960s on, the PRI faced increasing public opposition. Inside the PRI and the government some called for a response of economic liberalization (Teichman 2001), while others argued for a state-led, socially-minded alternative. A sub-group of the latter, led by Cuauhtémoc Cárdenas, left the PRI and formed the Frente Democrático Nacional (National Democratic Front, FDN) in support of Cárdenas's 1988 presidential campaign. 
Cárdenas probably won the election, but the PRI's Carlos Salinas was pronounced victorious after an engineered computer crash that delayed the publication of results. Salinas repressed perredistas (Castañeda 1993, Reding 1997, Bruhn 1997b, 1998) and revived clientelist deals with the lower classes, particularly through the new Programa Nacional de Solidaridad (National Solidarity Program, PRONASOL). While many members of the lower classes had voted for Cárdenas, they could not afford to antagonize the new administration by continuing to support him and thereby risk losing access to government resources (Bruhn 1997a) if not their lives.

In this hostile environment, Cárdenas and his supporters decided to form their miscellaneous front into a formal political party. Almost immediately, problems arose. The FDN lumped together a large variety of left-wing social and political groups, including communists, trotskyists, leninists, maoists, left-wing nationalists, social democrats, clandestine revolutionaries, opposition politicians, parastatal politicians (from PRI-sponsored opposition parties), and long-time priistas, joined by the desire to rid Mexico of the PRI (Bruhn 1997b). These currents had been able to co-exist effectively during the brief electoral campaign, but, as soon as the short-term goal of winning the 1988 elections failed, they had difficulties reconciling their ideological and strategic differences (Sánchez 1999, Semo 2003).

The founding currents are generally presented in three clusters for conceptual clarification, but they were far from internally homogeneous. The institutional, independent left represented by Heberto Castillo's Partido Mexicano Socialista (Mexican Socialist Party, PMS) was not a unified organization (Prud'homme 1996, 226). It was a recent agglomeration of leftist parties that had had to compromise in order to create one 
large entity that would make the left electorally viable. This turned out to be a much more center-left project than those espoused by a number of its members (Carr 1996, 306-7). The social left, made up of civil society organizations and movements, did not fit easily with these institutional groups, and was also the least internally coherent. It was constituted of associations that organized mass mobilizations, of armed guerrilla movements, of intellectuals, and of students. Many of the groups from the social left were informally organized and employed confrontational tactics with the government. These practices stood in opposition to the institutionalized processes and political moderation preferred by the old parliamentary left and most of the Democratic Current (see Martínez González 2003, 87-95).

Despite their common background, the ex-priistas under the banner of the Democratic Current were also not united in their opinions on and strategies for the PRD. Cárdenas argued for legal, institutional opposition to the PRI regime. His strategy was to continue organizing an electoral onslaught against the PRI at all levels: local, municipal, state, and national. This offensive was to be combined with "democratic intransigence", a policy of non-negotiation with, and non-recognition of, the Salinas administration, in order to safeguard the democratic movement's principles. Cárdenas felt that the democratic transition was necessary immediately and that a radical change was the only manner to bring it about (Galindo López 1990, Borjas Benavente 2003a, 289-96). Others, however, felt that the momentum of the people's support in the 1988 election should be maintained and used to pressure the regime to remove Salinas and install an interim government, until new elections could be held. In addition, they argued that funding and human resources should be expended on creating a solid party organization 
that would function according to formally established rules. An institutionalized party could then form alliances with other opposition forces and negotiate democratic reforms with the government (Muñoz Ledo 2000, 217-49, Martínez González 2003, 87-95, Borjas Benavente 2003a, 289-96, Sánchez 1999, 57-79, Prud'homme 1996, 242-3).

As the nationally recognized leader of the venture, Cárdenas had little difficulty in gaining the upper hand in the party. He benefited from his name, the loyalty of the supporters he had amassed during his time as priísta governor of Michoacán, the allegiance of the various smaller leftist groups that had joined the PRD and were looking to its charismatic head for leadership, and from his personal relationships with the members of the Democratic Current (Borjas Benavente 2003a, Prud'homme 1996). To increase his chances of success, he built alliances with other leaders. In addition, Cárdenas allied with the social left because it recognized the validity of his position. The primacy of his vision was essentially legitimated by means of his unopposed election to the party presidency at the First National Congress in November 1990 (Prud'homme 1996, 232-6, Corona Armenta 2004, 90, Martínez González 2003, 87-91). The immediate result of embracing Cárdenas's strategy was that the party was placed squarely into the electoral fray, forcing it to maintain broad support while facing the hostile PRI. Not all members of Cárdenas's Front joined the new party: some were unwilling to give up their independence (Valdés, 1994, 61) and others felt they could not afford to alienate the new PRI administration (Bruhn 1997a).

Attempting to maintain the loyalty of as many remaining supporters as possible, the PRD's founding statutes allowed for the existence of "currents, tendencies or convergences" in a democratic context, so that the diverse groups could preserve their 
individual identities. Given its opposition to the PRI and its methods, the PRD refused to use corporatist internal processes to organize its membership. ${ }^{\text {ii }}$ Permitting the existence of currents appeared to be the only option that would neither hinder the various groups' identities nor create corporatist sectors. Thus, according to the party statutes, all members had the right to form or join a current and, individually, or as a current, to voice opinions, propose policies and programs, and nominate candidates for internal election as well as pre-candidates for popular elections (PRD Estatutos 1993, Ch. 12, Articles 15, 16, 17). The statutes also set forth that democracy is the party's norm and decisions regarding statutes, programs, representative and directive organs, and candidates for popular election - will be made by affiliates in free and fair elections (PRD Estatutos 1993, Ch. 1, Article 2).

However, formally detailed procedures for structuring the currents and ensuring democratic processes were not elaborated. This lack of organization left inclusion of groups that failed to win positions of power in the party to personal relations with members of the executive, creating grounds for discretional representation. ${ }^{\text {iii }}$ The Executive itself was an empty shell, as Cárdenas directed the party from his personal offices with the help of an inner circle of trusted friends. Horizontal communication between currents or between the parliamentary bloc and the party did not exist (Prud'homme 1996, 233-4). Individuals developed personal relationships with Cárdenas, so that all information flowed through him (Corona Armenta 2004, 87; Sánchez 1999, 57-75 and 2001, 23-42) - the charismatic leader around whom the party is structured and from whom it becomes inseparable (Panebianco 1988, 52). 
As much as the PRD eschewed the PRI's corporatist methods, its currents began to resemble the PRI's camarillas, with an important disadvantage. The PRI was able to maintain unity among its camarillas because its hold on the state meant that all camarillas had the chance to access power sooner or later. The PRD, on the other hand, had little power and few resources to distribute, intensifying the struggle for access to what there was. Rather than drawing the PRD militants from different backgrounds together in a common project, the statutes are seen by some as having granted formal permission for internal wars (Ortega 2004, Martínez González 2003, 85).

The founding PRD currents were principle factions endorsing various leftist ideologies, organizational forms, and policy orientations. By the early 1990s, however, they took on aspects of personalist interest factions that served a particular leader and sought power and spoils (see Sartori 1976, 77-80 for a discussion of faction types). These factions continued to espouse particular ideologies - social democratic in a professional electoral structure, socialist in a mass-based structure, and various combinations thereof - that differentiated them. Yet, all were organized around a caudillo (strongman), who, in turn, looked to the party leader (the central caudillo). All maneuvered to access positions of power and redistribute the spoils of office to supporters. All entered conjunctural alliances with each other, negotiating for their own benefit.

Policy discussions, candidate selection processes, internal elections, and so on, soon became hostage to negotiations among currents attempting to increase their representational quotas and to direct party strategy. By the late 1990s, the struggle among these factions had degenerated to the point where internal electoral processes 
became undeniably corrupt, including ballot box stuffing with fake votes, ballot box theft, vote buying, membership list inflation, and member deletion from the lists of those qualified to vote (Corona Armenta 2004).

The rise of a second central caudillo in the PRD, Andrés Manuel López Obrador, further fragmented the party. López Obrador's was elected Federal District Head of Government in 2000 and used his position to advance the interests of the poor, whose plight has always been his primary concern. His social policies were so popular, and his persona of a frugal man of the masses unafraid to shake the establishment was so different from that of other politicians, that supporters in and outside the PRD began to look at him as a presidential hopeful for 2006. Thus, by 2004, Cárdenas was no longer the unquestioned central leader of the PRD, as a second pole had developed around López Obrador. The party was split into those loyal to Cárdenas and those in favour of the rising star.

Party unity and loyalty to statutory principles of democracy have been further weakened by López Obrador's pragmatism in strengthening his, and the party’s, national presence through alliances with a variety of external politicians and internal operators. His electorally successful "franchise operation" (Meyenberg and Carrillo 1999, 66) allowed non-perredistas to run for election on the PRD ticket. Pacts are created between the PRD leadership and individuals with significant political capital whose career in other parties has stalled. The politicians become PRD candidates for election in return for joining the party and bringing their followers with them (Meyenberg and Carrillo 1999, 65). Thus, in 1998, a number of priista politicians only recently converted to the PRD won state gubernatorial races - Ricardo Monreal in Zacatecas, Alfonso Sánchez Anaya in 
Tlaxcala, and Leonel Cota Montaño in Baja California Sur. In 1999, the list was expanded with Antonio Echavarría in Nayarit, and in 2000 with Pablo Salazar Mendiguchia (a coalition candidate) in Chiapas. Not only ex-priístas have benefited from the PRD franchise: in 2005, Carlos Zeferino Torreblanca, a businessman whose political ideology is closer to that of the PAN than the PRD, won the state of Guerrero, and Narciso Agundez Montaño, a former militant of the Workers' Party, succeeded Cota Montaño (who became party president) in Baja California Sur.

Former members of other left-wing parties joining the PRD is probably not inconsistent with the individuals' or the PRD's political programs. However, at times, the perredista desire to win elections has overshadowed principles, and candidates are courted based purely on calculation of who heads the best clientelist networks in a given state and is, therefore, the most likely to win elections. The 2004 gubernatorial candidacies of María del Carmen Ramírez García in Tlaxcala and José Guadarrama in Hídalgo were particularly divisive. Ramírez’s husband was outgoing Governor Sánchez Anaya, leading to questions of misuse of influence by the husband to promote the wife's campaign (and the party statutes prohibit immediate relatives of an incumbent from running for his position) (Díaz 2004). Guadarrama was a long-time priísta charged with responsibility for the deaths of PRD militants, as well as years of repressive activities in local politics, making many perredistas question the integrity of a leadership that could welcome such an individual into the party (Ibarz 2005). Unsurprisingly, the selection of franchisees fuels factional battles, as all sides try to outdo each other by bringing in possible candidates and tarnishing others' image. 
In discussions leading up to the eighth PRD National Congress in March, 2004, party leaders concluded that the factions exacerbate clientelism and corruption in their organization, and set out to regulate their activities in the amended statutes eventually approved at the Congress (Instituto de Formación Política del PRD 2004, PRD 2004). The attempt to regulate the activities of the currents is laudable, but its failure is predictable, given the process of increasing returns. It is not logical for any one faction or leader to adhere to the new statutes because it is unlikely that the others will do so. Since it is known that all the factions engage in clientelism, shady financing, and intrigue, a sure way for any one leader to disqualify himself from the battle over positions in the party, would be to introduce transparency to his faction's operations. While compliance with the new statutes could be beneficial to all perredistas in the long run, by creating trust and allowing them to work toward the same goal, the benefits of continuing on the established path in immediate decisions appear to them to outweigh long-term, uncertain gains. The longer these immediate benefits are chosen over long-term ones, the more difficult it becomes to deviate from the established path (see Pierson 2000, 252). In the PRD, the stakes were increased when it began to win elections.

\section{The PRD in Government}

Once the PRD won elections at the local and state levels, its factional disputes and power-seeking behaviour were carried into office. Now, power was related not only to influencing party strategies and gaining positions in the national congressional opposition, but to the political and economic benefits of forming governments.

When the PRD won the first democratic elections in the Federal District in 1997, its bench in the Legislative Assembly was clearly inexperienced. Its members were not 
only unsuccessful in seeking consensus with PRI and PAN representatives, but they and their colleagues in the executive were often motivated by factional interests, a tendency too obvious to conceal. Internal disputes occurred in the municipalities among administrators from different PRD currents, who saw themselves as powerbrokers (Águila and Salgado 1999, Ward and Durden 2002). In addition, clientelist deals intended to strengthen individual factions were struck between social organizations and politicians with access to public resources.

The Federal District is difficult to govern due to the size of this urban giant's population (close to 9 million) and its socioeconomic diversity. For example, demands from middle and upper class sectors for enhanced public security conflict with demands from the lower classes for employment and shelter. The former desire clean streets free of vendors, piratas (pirates, unlicensed taxi drivers often signaled as responsible for theft and kidnapping), and buildings or empty lots inhabited by squatters. The latter cannot find employment in the formal sector and demand the right to make a living, even if this takes place in an unregulated manner in the streets, and to have access to shelter. The PRD's official response to the dilemma has been to regulate street vending, take a tough stand against piratas, and evict squatters. Unofficially, however, party factions ally with vendor, taxi, and squatter organizations, using the electoral strength of the groups' backing to increase their bargaining power in negotiations for positions and policy direction inside the party. In return, they provide preferential treatment to the organizations' members. Thus, squatters from the Frente Popular Francisco Villa (Francisco Villa Popular Front, FPFV) have benefited from their leaders' alliance with 
one of the most powerful PRD factions in the Federal District by gaining comparatively better access to social housing credits than other citizens (Grajeda 2005).

Citizens unable to make such clientelistic alliances are clearly at a disadvantage. Thus, one social housing claimant, affiliated with a rival association to the FPFV, told me that when one goes to the Federal District's Instituto de Vivienda (Housing Institute, INVI), one is immediately struck by the difference in treatment of individual citizens seeking credit versus those represented by organizations such as her own and the FPFV. "When you get there, the first thing they ask you is whether you're represented" and if you are not, the authorities keep you waiting ("Isabel” 2004).

The inequalities generated by the PRD's clientelism are also visible in less conspicuous, daily governance activities. The faction in power in 2004 in the Federal District municipality of Iztapalapa, for instance, created a number of programs for senior citizens. At weekly meetings held in the community hall, seniors exercised, danced, chatted, and did crafts, but they also interacted with faction activists and were asked to participate in political events organized by politicians from the faction in power. On a monthly basis, the municipality provided baskets of basic food items to seniors. However, only those senior citizens whose signatures figured on each of that month's meeting attendance sheets, or who could excuse missed meetings by proving participation at political events, were given the food baskets. Senior citizens who chose not to involve themselves in these politically tinged meetings, or those who simply did not know about the programs, went empty-handed.

This is not to say that the PRD has not had successes in government. Cárdenas's Federal District administration created programs to reorganize and improve the public 
service, the criminal justice system, and the police force, to encourage citizens to denounce corruption, to alleviate unemployment, improve health policy and continuing education, and prioritize gender equity, and it revitalized the Historic Center. He was able to circumvent absolute domination by the federal government and maintain confidence in the feasibility of a democratic Mexico City (Baena Paz and Saavedra Andrade 2004, 225-9; Ward and Durden 2002). Subsequently, López Obrador continued and expanded many of the Cárdenas administration's programs. Among other things, he subsidized seniors' nutrition, children's school supplies, and health care for vulnerable sectors of the population, created commissions and financing to improve access to subsidized housing, and allied with business to rebuild the downtown financial district.

Yet, the processes underlying these successes - and hindering further advances are marked by the factionalism and clientelism we have already seen, as well as by a lack of institutional commitment. Thus, López Obrador's devotion to the poor and aversion to traditional elites have led him to work for and protect the interests of the former through sometimes unorthodox or even extra-institutional means. Commissions to ensure transparency in administrative spending or to evaluate the economic status of subsidy recipients are, in his eyes, an unnecessary waste of funds that should go directly to the poor (García Ochoa 2004, Juárez Vázquez 2004, Trelles and Zagal 2004). While this dedication is laudable, its long-term repercussions for democratic governance processes are questionable.

Other PRD administrations' ambitious projects have also been undercut as a result of the party's unregulated dynamics. In the municipality of Nezahualcóyotl, Mexico State, the PRD won the mayoralty in 1996, and then again in 2000 and 2003. Having 
been preceded by decades of PRI administrations, it immediately set about creating more transparent government processes. For example, Neza's PRD began to generate threeyear development plans, annual mayoral reports, and internet-based budgetary documents that provided citizens with previously unimaginable levels of access to information (Selee 2006).

However, mechanisms allowing for autonomous citizen participation in political processes were short-lived, as they curtailed the ability of the local PRD factions to negotiate positions and policy. Thus, open primaries for selecting PRD candidates for mayor and city council positions were held only briefly since the factions preferred bargaining amongst themselves to divide up the available positions. Local administrations also considered federally mandated community councils for participation in certain budgetary decisions too vocal and allowed them to become factional and partisan bodies. Other participatory councils quickly became little more than arenas in which social leaders and individual citizens negotiate urban services and personal favours with local politicians. Even city council meetings, intended to be weekly and public, are held infrequently and without prior notice, making it difficult for citizens to access information regarding the municipal government's actions before decisions are made (Selee 2006). In sum, although more information about government actions and budgets is now available to Neza citizens, it is published ex post facto. Since fora for public participation in governance are held hostage by partisan and factional elements, personal relationships and clientelism continue to be fundamental elements of citizen demandmaking. In Michoacán, local PRD administrations did not even attempt to institute 
anything like popular councils for fear that they would just be taken over by the factions anyway (Bruhn 1999).

The factionalism and clientelism apparent in its municipal and state governments are far from the participatory, democratic processes emphasized in the PRD's official discourse (see Harbers 2007), but they are relatively harmless in comparison to what has occurred in at least one other local PRD government. Citizens of Neza and the Federal District may freely choose - with a material loss - to exit relationships with the PRD, but members of alternative organizations in Zinacantán, Chiapas, have faced repression by PRD authorities in a manner reminiscent of the PRI. ${ }^{\text {iv }}$ In the Zinacantàn area, political power is held by a number of violent local strongmen, many of them former priistas who crossed to the PRD when they were expelled from their own party (Bellinghausen 2004a). In 2003 and 2004, Zinacantán's mayor and other PRD militants cut off potable water supplies, verbally harassed, and physically threatened Zapatista activists unwilling to participate in local government activities. When other Zapatistas organized to bring water to their comrades, their convoy was attacked by government forces, an episode resulting in a number of injured Zapatistas, families fleeing their homes, and five disappeared (Bellinghausen 2004b). In addition, the correspondent for the national paper La Jornada reported being under surveillance by local police informants as a result of his coverage of the events (Bellinghausen 2004c). In some instances, unwillingness to support a PRD administration thus leads to more dire consequences than the loss of clientelistic benefits.

To be sure, the impetus for clientelistic deals has not come from PRD politicians alone. Many of the social movements that joined the party in its formative years, and 
others that now seek advantages from an alliance with the PRD in power, have a long history of clientelist links with PRI politicians and officials. It is also common for such organizations to structure internal relationships with their membership according to clientelistic rules. These are not necessarily associations that aimed simply to exploit their members, but included groups that were highly successful in defending their adherents' interests vis-à-vis public officials (see Haber 2006, Hellman 1994a, Cross 1998). Nonetheless, their organizational experience and expectations regarding relationships between citizens and politicians affect the PRD in government. As one founding member of the PRD with a long previous history in left-wing opposition politics told me, "when you form a group that brings together existing leaderships, such as regional movements that have been fighting other movements for existence, you're going to be bringing in their clientelistic practices" (Guerra 2004).

For many members of social organizations and individual citizens the "gestión" is at the heart of politics. It describes the arrangements politicians and their operators make to fulfill citizens' needs for electricity, sewage, gutters, legal advice, social events, health care, and so on. Gestiones are what draw the interest of the lower classes to politicians they want to know what politicians will do for them - and politicians know, or learn, how to use this tool (see Tejera Gaona 2003).

The types of services typically provided through gestiones should be made available to all citizens by municipal governments, but these often do not have enough resources to cover all of their constituents' needs. Approximately $48 \%$ of the Mexican population is considered poor by the World Bank (2006). The poor as a sector of the population have few chances of receiving aid from their resource-strapped governments, 
but they can help themselves as individuals by forming relationships with social and political leaders. The latter step in as brokers to organize individuals in need and represent them at various government agencies. The backing of their membership, in turn, gives the leaders of these organizations significant political capital. Citizens successful in gaining the resources they sought through these relationships tend to be grateful for the negotiating role played by the people who represented them. The norm of reciprocity (Gouldner 1977) translates into political support.

As the PRD became electorally successful - particularly through its 1997 victory in the Federal District - and gained access to public resources, growing numbers of individual and organized citizens looked to perredista politicians as possible patrons in clientelist bargains. The desire of certain sectors of the public to engage in such alliances further reinforced trends toward clientelism in the PRD, as the factions readily used such pacts to surpass each other's size of public following.

Nonetheless, the additional pressure towards clientelism coming from societal groups and individual citizens does not negate the hypothesis that Cárdenas's charismatic leadership and the lack of party institutionalization resulting from his strategy are the keys to understanding the roots of clientelism in the PRD. The Brazilian Partido dos Trabalhadores faced constraints very similar to those encountered by the PRD - including a long tradition and continuing culture of clientelism - but made significant strides to overcome these through a commitment to participatory democratic regulations.

\section{The Partido dos Trabalhadores}

The PT was formed when the Brazilian military regime (1964-1985) opened its artificial two-party system to the creation of real opposition parties in 1979. At about the 
same time, a series of important labour strikes shook the nation and garnered a great deal of media attention, but were relatively unsuccessful in having their material demands met. Labor leaders realized that they needed to engage in political action at the national level in order to create a more propitious context for workers to make their demands. Taking advantage of the new election law, they joined with progressive intellectuals and opposition politicians to create a workers' party (Keck 1992).

The sociopolitical environment in which the PT developed was similar to that faced by the PRD in Mexico in a number of ways. Although the Brazilian regime was in a process of abertura (opening), the transition was slow and marked by violent repression of union activists - many of them PT members. Important social sectors had been linked to the regime through a corporatist structure intended to facilitate social control (Keck 1992). Social subjugation had also historically been ensured through clientelism and the military allied with local and regional strongmen to guarantee the quiescence of their clients (Hagopian 1996). In fact, much like Mexico, Brazilian politics continues to be structured around clientelism (Avritzer 2000) and society is marked by a general culture of clientelism, in which citizens evaluate the work of politicians according to their local engagements and direct impact on improving the citizens' lives - through public works, urban services, personal favors, and so on (Nylen 2003, 102). This is exacerbated by widespread poverty, at a level of about $38 \%$, and high socioeconomic inequality (World Bank 2007).

In addition to these contextual factors, the PT as a political party shares several significant characteristics with the PRD. Much as the PRD's early existence hinged on Cárdenas's leadership, the PT depended on the persona of Luis Inácio Lula da Silva. 
Furthermore, although the PT was formed as a workers' party, it has never been constituted by industrial workers only, but includes all manner of left-wing social and political groups, intellectuals, white collar workers, Christian Base Communities, as well as new social movements. It did not take long for the more radical of these groups to start fighting with each other and with those having a more reformist orientation, creating a factionalized party (Keck 1992). Finally, many of the social organizations that have sought alliances with the PT in government are little more than local leaderships interested in solidifying their political status by negotiating material benefits for their clients with the party (Nylen 2003, Baiocchi 2003). Even the labour unions that constituted the heart of the PT in its formative years had long histories of clientelistic relationships with the government (Keck 1992). The charismatic leadership, factionalism, and tradition of clientelism that characterized the PRD in Mexico were, thus, also important factors in the Brazilian PT.

On first view, contemporary clientelism would appear to be another similarity between the PT and the PRD, yet a closer look reveals that moderation is necessary in this comparison and points to the problems associated with minimalist definitions of clientelism. According to a great number of sources, the PT is increasingly using clientelistic mechanisms for building political support. As the PT shifted from the left to the center-left of the political spectrum in the 1990s, its discourse moved from democratic socialism to a more catch-all, progressive approach (Hunter 2007). Coupled with its ascendance to national power in 2000 , this shift has led it to strike alliances and advocate programs that are termed clientelistic by pundits and critics. Such reports seem to be based on something approaching the parsimonious economistic understanding of 
clientelism - a simple trade of support for benefits - described above. In reality, there has been vote buying and patronage at elite levels of the national PT administration, as well as policy that could be described as pork-barreling (but likely is not even that). However, these phenomena do not resemble the grassroots relationships tying citizens to the PRD in a system where two individuals of unequal status engaged in a face-to-face interaction exchange material benefits for political support over a period of months or years - i.e. the real stuff of clientelism. As much as such relationships involving PT officials and citizens may exist (see Keck 1992, 212-214), the PT has made significant strides toward using non-clientelistic community-building mechanisms and the "clientelism" for which the PT has been so heavily criticized in recent years - its corruption scandals and targeted social programs - are not really clientelism. Employing a minimalist definition, one begins to label a wide range of behaviour clientelistic, diluting the explanatory power of the concept. Patronage, vote-buying, and clientelism are similar in certain aspects and often occur together, but they are not the same and should remain conceptually differentiated.

The most widely noted supposed examples of clientelism in the PT are the mensalão (big monthly) and caixa dois (second fund) (see Avritzer 2006). The mensalão refers to an arrangement by which national congresspeople from other parties received monthly payments from the ruling PT in return for supporting PT policies. While there is a long-term exchange involved here, it is a matter of vote buying (on the part of the PT) and of corruption (on the part of recipients) among high-level elites with relatively equal positions of power, not a relationship between a powerful patron and a dependent client. The caixa dois is a slush fund that has been used to finance PT elections - again, a matter 
of corruption, not clientelism. The PT has also been employing patronage. The Brazilian president has unequaled discretion in appointing thousands of administrative officials, a power Lula has used to reward loyal petistas, rather than employing merit-based criteria (see Wainwright 2005, de Oliveira 2006). I do not wish to refute that these activities occur, but to point out that they constitute patronage, not clientelism.

Finally, critics charge that the PT uses social programs like the Bolsa Família (Family Grant) to convert the Brazilian masses into clients of the state (de Oliveira 2005, Hunter and Power 2007). The program provides a small, monthly subsidy to poor families who must send their children to school and have them vaccinated in order to qualify. Opponents argue that the Bolsa Família demobilizes citizens, transforming them into helpless dependents rather than teaching them to organize and make demands. Yet, program implementation is decentralized and some communities use participatory mechanisms to shape its outcomes in a very empowering process (Aidar Prado and Moassab 2007). To be sure, in some communities the subsidies are simply hand-outs and Lula has benefited electorally from the program. However, this is not even porkbarreling, let alone clientelism, since the program is aimed at an entire sector of the Brazilian population rather than at a territorially definable group and forms part of a clear, long-term platform for easing poverty. Yet, even the careful analysis of Hunter and Power (2007) points to the Bolsa Família as a modern type of clientelism, though the authors do indicate that the program is universally available to the targeted sector of the population and no reciprocity is required and, thus, do not make clear how it differs from the regular stuff of politics. What is clear is that the PT has, indeed, fought clientelism at 
the grassroots, more or less successfully instituting participatory democracy both in local government and in party structures (Abers 1998, Baiocchi 2003).

Given the otherwise similar contexts and characteristics, why has clientelism become so much more central in the PRD than in the PT? The key differentiating factor explaining the diverging paths of the two parties appears to be their initial strategy. In the PRD, Cárdenas's conviction that a transition to democracy required ousting the PRI as quickly as possible through institutional means resulted in focusing all resources on elections. Lula and other PT leaders, on the other hand, felt that winning elections alone was not enough, since governments would remain clientelistic and exclusionary, limiting the amount of change possible from above. Convinced that democracy had to be brought about from the bottom up, petistas in local government began to use popular councils to generate participation. This not only matched their worldview, but was considered the best available strategy for countering the entrenched culture of clientelism (Nylen 2003, 47-48). The PT's early concern with building its organization and seeking policy change significantly affected its development path (Hunter 2007, 456, 465-8).

Thus, petistas developed democratic rules and regulations to govern life in the party. The PT statutes not only call for participatory fora and elections at all levels, but the rules are strictly followed. Individuals wanting to gain party candidacies for elected office are chosen carefully to ensure the compatibility of their political vision with that of the party - including in the case of alliance or coalition candidacies. Factions were regulated early on and forced, among other things, to undergo registration by the party. Today, a number of PT factions even have their own internet sites, explaining their vision and activities. Party unity is also strictly enforced. The Brazilian Congress is notorious 
for party representatives voting as though they were independent, yet the PT makes sure that its representatives adhere to the party platform. According to Samuels (2004), the institutionalization of democracy in the PT has been so solid that it is, in fact, responsible for the party's ideological shift to the center-left. Rules guaranteeing the weight of members' voices ensured that the growing political pragmatism among industrial workers and the increasingly important sector of white-collar workers with reformist views in the party were translated into a party leadership and candidacies for elected office with similar perspectives. While Hunter (2007) disagrees as to the causes for this shift, she concurs that the PT's solid democratic bases have kept it from becoming a catch-all party like all the others in the Brazilian electoral arena.

In government, the PT has developed a series of community councils to stimulate the direct participation of citizens in political decision-making. These have made important strides toward forestalling clientelism and educating citizens regarding their rights and responsibilities (Abers 1998, Avritzer 2000, Baiocchi 2003, Nylen 2003). Some PT administrations have, of course, been less successful than others. There are cases in which the PT has not been reelected due to local dissatisfaction with the government's activities and ones in which citizens revert to clientelism as soon as the PT is voted out (Nylen 2003).

In sum, corruption, vote-buying, and patronage in the elite spheres of the PT are the results of inserting the party fully into the electoral game in the 1990s. The shift in strategy from seeking policy change to seeking power meant that the pressure of maximizing votes increased, making the party more vulnerable to the institutionalized patronage and corruption of Brazil's political system (Hunter 2007, 456, 465). It appears 
that lower level PT politicians, officials, and activists are as stunned and disgusted by these events as the public and critics, and that the guilty parties did not use the various funds for personal enrichment or advancement, but rather to help the cause of the PT (Wainwright 2005, Avritzer 2006). While this does not mitigate the gravity of the corruption, it does lend further support to the evidence showing that the party's ideals of democratic participation have not been damaged by clientelism at the grassroots. Thus, the PT appears to have staved off clientelism to a greater degree than the PRD. As much as the PT's woes highlight the stretching that can result from minimalist definitions, the PRD's activities underline the continuing importance of discussions regarding the ambiguous relationship between clientelism and democracy.

\section{The Clients' Perspective}

From the perspective of civilians involved in relationships with PRD politicians as clients, the impact of these links can be complex. The cases presented in this section illustrate that clientelism is not necessarily a non-democratic exchange of support for benefits. ${ }^{\mathrm{v}}$ The patron-client relationship is a complex interaction from which both parties always draw benefits. To be sure, a fine line divides exploitation and acceptable burdens and short-term gains may be outweighed by long-term losses, but power and trust, individualism and community interact and confront each other. In certain instances, clientelism may be the best available mechanism for holding politicians and officials accountable and in some cases it may even result in community-building. Clientelism at the grassroots is replete with political tensions that are essential elements of the phenomenon. 
Beatriz and her sister were young, single women when they decided to join the Frente Popular Francisco Villa because they could think of no other way to get enough capital and clout for access to subsidized housing. They were required to pay an initial deposit into a cooperative fund and weekly fees of ten pesos to the leadership, attend meetings every Sunday, protest in front of prisons holding members of the organization, demonstrate at the Social Housing offices, and attend rallies commemorating events such as the 1968 student massacre. Once the FPFV allied with the PRD, mobilizing for the party was also obligatory. Beatriz told me that all of the activities "really wore you down" ("Beatriz" 2004). She persevered and eventually received her apartment, but many other members either left the organization or devised tricks to avoid participating.

Shirking participatory obligations could be expensive if not done right: at demonstrations,

people go, look for the person who writes down that you were there, and then leave. That's what I did. But, if you don't go at all, you have to pay a fine between 30 and 50 pesos. The idea is that you pay this so that they can pay someone else to go in your place, but they never end up giving that person the full amount. Those who collect the money keep some of it. But, none of this matters because as long as you don't have a house, you do whatever they say to get it. And you say whatever it is they tell you to say: down with the PRI, down with the PAN. Once you already have a house, you stop going. The Frente enslaves people. It exploits them as much as it can ("Beatriz" 2004).

Leaving the organization implied even heavier financial losses. Members paid into a cooperative fund for their construction projects and Beatriz explained that it was very difficult to have this money returned if one wished to exit the FPFV. It seems that the leaders kept the funds, betting on the odds that former members did not have the resources to pursue the matter legally. Regardless, Beatriz claimed that some people 
were disgusted enough by the FPFV's requirements to leave despite the financial repercussions. Though she persisted, she felt so manipulated that she came to regard the organization, the party, and the entire political left as corrupt. From the moment she got her apartment, she stopped participating in anything political.

Unlike Beatriz, some clients draw a lifetime of benefits from clientelistic relationships. Many settlers living in housing organization shanty-towns while they save for down-payments on subsidized apartments not only see their situation pragmatically, but also feel relatively at home in their communities. When I met Luisa, she was living in a shanty community run by the FPFV. In fact, she had been living in such communities longer than the organization had existed: she was part of the massive 1988 expulsion from Lomas del Seminario that was one of the sparks leading to the foundation of the FPFV. When she was forced to leave El Seminario, she moved to Cabeza Juárez in Iztapalapa, one of the largest FPFV housing developments, and in 2001 to the community where I met her. There, she inhabited a one-room dwelling with her daughter, daughter-in-law, and grandchildren. Luisa liked the way the FPFV was organized - she was in accordance with being asked to take part in FPFV activities in return for the privilege of the leaders' protection, and she was happy living in her community. "We feel at home here and in the organization" ("Luisa" 2004).

Luisa was unemployed, making it unlikely that she would be able to contribute enough to the FPFV cooperative fund to access an apartment in the organization's government subsidized projects. Nonetheless, she continued - after more than 20 years to live in shanties under FPFV protection from eviction by government authorities. That the PRD in government develops policies to aid people like Luisa while also attempting 
to control them is evidence of the difficulties inherent to governing the urban monstrosity

of the Federal District with its poor and wealthy divides, as we have already seen.

Luisa was not alone in willingly spending much of her life in shanty-towns run by social housing organizations. This is not an unusual phenomenon, and one that points both to the dire situation in which many poor housing claimants find themselves in Mexico City and to a fact we already know: that these clientelistic organizations are highly useful for their members. Carlos, an FPFV leader, told me,

Sometimes, I don't know who uses whom. The FPFV is criticized for using the poor, but the poor also use the organization to get what they want. In the end, they get their apartment and in the meantime they pay their 30 pesos per week in dues and other than that they get to live for free. Twenty-five years ago, during the invasion of Belvedere, there was this 80 year old woman, Doña Tachita, that everyone was looking out for, to make sure she wasn't too cold in her cardboard shack, that she didn't get hurt in the violence, and so on. But then, slowly, we came to realize that she had already been in other invasions - the Santo Domingo one that was the biggest one in the Federal District, and later on another one. This was how she lived. She invaded and then, when the land was hers, she'd sell it, making more money than she could have done in a regular job, and then she'd go and invade somewhere else. She's not the only one who does this. So, who uses whom ("Carlos" 2004)?

Clearly, members pay a price - time, money, and the danger of being fleeced by leaders - for the housing and protection they stand to receive from the FPFV. Because the FPFV organizes the poorest of the poor in Mexico City, its members have few resources and fewer alternatives and are willing to incur relatively high costs to reach their goals (see Kitschelt and Wilkinson 2007). Some, such as Luisa, feel this to be a fair 
bargain, while others, such as Beatriz, become disenchanted with political action as a result of their clientelistic experiences.

Elena, a lifelong activist, expressed outrage at what she regarded as the exploitation of the poor in organizations such as the FPFV, but was just as concerned about the long-term effects of clientelism on the broader left-wing political project. She had been involved in the Movimiento Urbano Popular (urban popular movement, MUP) that protected and promoted the social housing rights of the urban poor under the PRI in the last three decades of that party's rule. She and many of her friends supported Cárdenas in 1988, and in the early 1990s a great number of the MUP's leaders joined the PRD to continue their struggle in the political arena. However, Elena now felt that the PRD's social policies were not structured properly.

López Obrador's social politics is individualist and personalist ... they're removing people's organizations and individualizing things and tying them directly to the party and to López Obrador himself. Is this what it means to be leftist? The movements are paralyzed now because with the current government, it's like they've won, but things aren't getting done, yet it's hard for people to mobilize against their own government ("Elena" 2004).

Elena admitted to being disillusioned because the PRD fell far short of her expectations by doing politics using the same clientelistic methods as the PRI and, thereby, demobilizing citizens.

The critiques leveled at clientelism by those who have experienced it first-hand, such as Beatriz and Elena, and by those who have studied the phenomenon (see, for example, Flynn 1975, Singelmann 1981, Putnam 1993, and Kurer 1993) are noteworthy. As much as Luisa's and Doña Tachita's - and even Beatriz's - stories show that 
clientelism could not function if there were not some significant benefit to the client, the interaction involves more than performing a task in return for material gain. It entails elements of power and trust that have important personal and sociopolitical repercussions. Some clientelistic relationships lead to feelings of exploitation and reactions of political disengagement, while others result in feelings of belonging and security. Güneş-Ayata (1994) argues that modernization and democratization free individuals but also atomize them, rendering them powerless to access needed resources in the free market. In this context, clientelism provides access to market resources and to community - a sense of belonging to some larger unit

According to my research, in some cases the individual benefits derived from forming part of a clientelistic group also have positive repercussions for the collectivity and for political participation. Some of the poor clients I interviewed in Mexico City had initiated clientelist links with social organization leaders or political brokers in order to meet personal needs, but learned from these relationships that they could help their community and thus became socially or politically engaged citizens. These people came to see the importance of the activities that are a required aspect of the exchange bargain. Participation at association meetings, in research groups, at political rallies, at classes on the political process, and so on, is compulsory in many social organizations that are linked to the PRD. Many clients do not put much thought into what goes on at such gatherings and others consider them an imposition, but some become more socially and politically active due to their experiences with clientelism.

Iginio spoke with me after a meeting of his social housing organization. He told me that his activities with the organization and the PRD resulted in his family's 
ownership of a government-subsidized apartment. Although he had reached his initial goal, he considered it important to keep working for the organization and convince others to do the same.

I have my house now. As I got ahead, I realized that others were getting the same thing I was. I realized that we were receiving something like a subsidy in terms of the help of the people in the organization. Now, I feel that I have to give something back. We have to keep the organization running for services and to help those who have even less than we ("Iginio" 2004).

He pointed out that the scarcity of social housing in Mexico City and the trend of family disintegration cause social and economic difficulties for the poor. To combat these problems, his group attempted to integrate people, teach them skills, and assist them. Crafts made by a women's commission were sold to help the family economy, there were programs to keep youths out of trouble, and once a month everyone contributed a little bit to a worthy cause, such as buying a wheelchair for a disabled member of the organization.

Isabel, a member of another housing organization, explained how the clientelist exchange functions.

They're giving you a kind of schooling, such as the habit of participating in something on a weekly basis. They are teaching us and manage us with points for participating. We go to the meetings and then you have to go to other events. Going to the meeting is worth one point and events depend on what the leaders give. Those with the highest points get to choose their apartment first ("Isabel" 2004).

Although Isabel said she was being "managed", she did not see her involvement in politics in a negative light, "I don't feel manipulated because I do like to participate [...] I 
like to learn and to understand what's going on in politics [...] I've learned a lot from [the patron]" ("Isabel" 2004). She explained that she became more and more involved in politics because she wondered why people mobilize and then realized that demonstrations are a type of pressure that forces the government to work and to respond to citizens' demands.

Iginio and Isabel became involved in their respective organizations for personal reasons - they were trying to better their housing situation - but took from their experiences much more than satisfaction of their initial goals. They learned about the responsibilities of citizenship and took these on as their own, using clientelism as a springboard for community-building. Yet, as we have seen, their experiences are not necessarily shared by other clients: some feel isolated and exploited and become politically detached, while others simply continue to use the clientelistic community for their own benefit.

Power, dominance, exploitation, and individualism are significant elements of clientelism, as much as community, trust, mutual benefit, and reciprocity. The tensions among these aspects generate positive and negative effects, both internally and externally to the relationship itself. These tensions are fundamental aspects of clientelism and should be reflected in definitions and discussions of the phenomenon.

\section{Conclusion}

The individuals who appear to continue being active in their communities and participating in politics as a result of their experiences with clientelism are not the poorest of the poor and are not involved in highly exploitative relationships with their patrons. They are people who enjoy a relative level of economic stability - they are employed and 
own property (often as a result of clientelistic bargains) - and who mention having some education and an interest in continuing to learn. The patrons with whom they have had their most significant clientelistic relationship may be authoritarian, but are relatively fair and truly concerned for the well-being of their clients.

Further research is required to establish a more definitive profile of these participators, but for the moment it is interesting to point out an apparent overlap with individuals identified by Nylen (2003, ch. 6) as likely to remain mobilized after participation in the PT's community councils. The latter tend to have past histories of community involvement (prior to the PT councils) and, though poor, are relatively wealthier than the worst-off segments of the Brazilian population. It would be interesting to study the implications of this overlap (if it holds upon further investigation into the characteristics of perredista clients). Is there a profile of "participators" who are going to mobilize even if the mechanisms are not ideal?

The problems resulting from recent definitions of clientelism - conceptual stretching and decreased explanatory power - also deserve further attention. In-depth definitions of clientelism are rooted in relationships observed by researchers in traditional agrarian communities. As these societies modernized, the relationships were transposed onto widening market and political networks and researchers following these developments began to tinker with the definition of clientelism, minimizing its personal elements in favor of broader, non-universal political exchanges. In the post third-wave transitions era, clientelism has become synonymous with the remnants of non-democratic regimes that continue to complicate democratic consolidation. Yet, clientelistic relationships are often more democratic than revealed by this assumption and should be 
differentiated from phenomena such as vote-buying and corruption with which it is often equated. As a result, the oft-noted causal link between clientelism and weakly institutionalized democracy may also need to be reexamined.

Despite its weak institutionalization, factionalism and clientelism, the PRD continues to be an interesting alternative in the Mexican political arena to the conservative PAN and the chameleon-like PRI, and has enough electoral support to remain viable. In fact, López Obrador's extremely popular Federal District social programs gave the party more votes (and a near victory) in the 2006 presidential race than it had been able to garner since Cárdenas's fraudulent defeat in 1988. The PRD is difficult to navigate due to its informal rules and regulations and these make it less competitive in the electoral arena than it could be if all of its members were working together. Nonetheless, its governance of Mexico City and plans for the country continue to give millions of Mexicans - from across the socioeconomic spectrum - hope for a different, more egalitarian future.

\section{Bibliography}

Abers, Rebecca. 1998. From Clientelism to Cooperation: Local Government, Participatory Policy, and Civic Organizing in Porto Alegre, Brazil. Politics \& Society. 26(4): 511-537.

Águila Franco, Carlos, and Luis M. Salgado. 1999. La Ciudad que entró en Caos: Análisis de las notas informativas del primer año de Gobierno de Cuauhtémoc Cárdenas. México, D.F.: authors’ publication. 
Aidar Prado, José Luiz, and Andréia Moassab. 2007. O programa Bolsa Família na revista Veja: do assistencialismo à emancipação. Paper presented at the $X V I$ Encontro da Compós, Curitiba, Paraná.

Auyero, Javier. 1999a. "From the client's point(s) of view": How poor people perceive and evaluate political clientelism. Theory and Society. 28: 297-334. . 1999b. Performing Evita: A Tale of Two Peronist Women. Journal of Contemporary Ethnography. 27 (4): 461-493.

Avritzer, Leonardo. 2000. Public Deliberation at the Local Level: Participatory Budgeting in Brazil. Paper presented at the Experiments for Deliberative Democracy Conference, Wisconsin. 2006. A crise do governo Lula e a crise do P.T. Reprinted from Jornal do Brasil, June 20, 2006, www.cultiva.org.br/politica.php. Accessed Dec. 5, 2007. Baena Paz, Guillermina, and Gisela G. Saavedra Andrade. 2004. Entre tribus y jefes: el futuro del PRD en el 2006. In Partido de la Revolución Democrática: Los problemas de la institucionalización, ed. Francisco Reveles Vázquez. México, D.F.: Universidad Nacional Autónoma de México y Gernika. 217-275.

Baiocchi, Gianpaolo, ed. 2003. Radicals in Power: The Workers'Party and Experiments in Urban Democracy in Brazil. New York / London: Zed Books.

“Beatriz". Former member of the Frente Popular Francisco Villa. Author interview. Mexico City, Nov. 24, 2004.

Bellinghausen, Hermann. 2004a. Admite el edil de Zinacantán que envió patrullas para bloquear a los zapatistas. La Jornada, Mexico City, April 14, 2004. 
. 2004b. Persecución selectiva en Zinacantán. La Jornada, Mexico City,

April 15, 2004.

2004c. Hermann Bellinghausen denuncia espionaje a sus actividades en

Chiapas. La Jornada, Mexico City, April 13, 2004.

Borjas Benavente, Adriana. 2003a. Partido de la Revolución Democrática: Estructura, organización interna y desempeño público. 1989-2003. tomo I. México, D.F.: Gernika.

Bruhn, Kathleen. 1997a. The Seven-Month Itch? Neoliberal Politics, Popular Movements, and the Left in Mexico. In The New Politics of Inequality in Latin America: Rethinking Participation and Representation, eds. Douglas Chalmers, et. al. New York: Oxford University Press. 144-170. . 1997b. Taking on Goliath: The Emergence of a New Left Party and the Struggle for Democracy in Mexico. University Park: Pennsylvania State University Press.

. 1998. The Partido de la Revolución Democrática: Diverging Approaches to Competition. In Governing Mexico: Political Parties and Elections, ed. Mónica Serrano. London: Institute of Latin American Studies. 114-136. 1999. PRD Local Governments in Michoacán: Implications for Mexico’s Democratization Process. In Subnational Politics and Democratization in Mexico, eds. Cornelius, Eisenstadt and Hindley. La Jolla: Center for U.S.-Mexican Studies. $19-48$. 
. 2003. "New Access or New Corporatism? Urban Popular Movements

after the Democratic Transition in Mexico and Brazil." Paper presented at the 2003 meeting of the Latin American Studies Association in Dallas, Texas.

Brusco, Valeria, Marcelo Nazareno, and Susan C. Stokes. 2002. "Clientelism and Democracy: Evidence from Argentina." Paper presented at the conference on Political Parties and Legislative Organization in Parliamentary and Presidential Regimes. Yale University, March 2002.

“Carlos”. Frente Popular Francisco Villa leader. Author interview. Mexico City, Dec. 8, 2004.

Carr, Barry. 1996. La izquierda mexicana al través del siglo xx. México, D.F.: Ediciones Era.

Castañeda, Jorge G. 1993. Utopia Unarmed: The Latin American Left After the Cold War. New York: Vintage Books.

Centeno, Miguel Ángel. 1997. Democracy within Reason: Technocratic Revolution in Mexico. $2^{\text {nd }}$ ed. University Park: Pennsylvania State University Press.

Collier, Ruth Berins and David Collier. 2002. Shaping the Political Arena: Critical Junctures, the Labor Movement, and Regime Dynamics in Latin America. $2^{\text {nd }}$ ed. Notre Dame: Notre Dame University Press.

Corona Armenta, Gabriel. 2004. La renovación de las dirigencias nacionales en el Partido de la Revolución Democrática (1989-2002). In Partido de la Revolución Democrática: Los problemas de la institucionalización, ed. Francisco Reveles Vázquez. México, D.F.: Universidad Nacional Autónoma de México y Gernika. 73133. 
Cross, John C. 1998. Informal Politics: Street Vendors and the State in Mexico City. Stanford: Stanford University Press.

Díaz, Gloria Leticia. 2004. El PRD, entrampado en la 'novela tlaxcalteca'. Proceso. www.proceso.com.mx/noticia.html?nid=27074\&cat=0. Accessed June 29, 2007.

"Elena". Urban Popular Movement member, advisor for technical assessments of social housing projects for the Centro de la Vivienda y Estudios Urbanos. Author interview. Mexico City, Oct. 18, 2004.

Fernández-Kelly, Patricia, and Jon Shefner, eds. 2006. Out of the Shadows: Political Action and the Informal Economy in Latin America. University Park: Pennsylvania State University.

Flynn, Peter. 1975. Class, Clientelism, and Coercion: Some Mechanisms of Internal Dependency and Control. Journal of Commonwealth and Comparative Politics. 12 (1): 133-56.

Fox, Jonathan. 1994. The Difficult Transition from Clientelism to Citizenship: Lessons from Mexico. World Politics. 46 (2): 151-84.

Galindo López, Jesús. 1990. A Conversation with Cuauhtémoc Cárdenas. Journal of International Affairs. 43: 395-406.

García Ochoa, Juan José. Federal Congressman, PRD. Author interview. Mexico City, Oct. 21, 2004.

Gay, Robert. 1999. The Broker and the Thief: A Parable (Reflections on Popular Politics in Brazil. Luso-Brazilian Review. 36 (1): 49-70. 
Gouldner, Alvin W. 1977. The Norm of Reciprocity: A Preliminary Statement. In

Friends, Followers, and Factions: A Reader in Political Clientelism, eds. Schmidt,

Guasti, Landé, and Scott. Berkeley: University of California Press. 28-43.

Grajeda, Ella. 2005. Benefician perredistas con créditos de vivienda. El Universal,

Mexico City, Jan. 16, 2005, Ciudad, p. 2.

Guerra, Juan. Head of Administrative Modernization Coordination and Planning,

Municipality of Tlalpan. Author interview. Mexico City, Dec. 6, 2004.

Güneş-Ayata, Ayşe. 1994. Clientelism: Premodern, Modern, Postmodern. In Democracy,

Clientelism, and Civil Society, eds. Luis Roniger and Ayşe Güneş-Ayata. Boulder:

Lynne Rienner. 19-28.

Haber, Paul L. 2006. Power from Experience: Urban Popular Movements in Late

Twentieth Century Mexico. University Park: Pennsylvania State University.

Hagopian, Frances. 1996. Traditional Politics and Regime Change in Brazil. Cambridge:

Cambridge University Press.

Harbers, Imke. 2007. Democratic Deepening in Third Wave Democracies: Experiments with Participation in Mexico City. Political Studies. 55: 38-58.

Hellman, Judith Adler. 1988. Mexico in Crisis. $2^{\text {nd }}$ ed. New York: Holmes and Meier. 1994a. Mexican Lives. New York: New Press. 1994b. Mexican Popular Movements, Clientelism, and the Process of Democratization. Latin American Perspectives. 21 (2): 124-42.

Hunter, Wendy. 2007. The Normalization of an Anomaly: The Workers' Party in Brazil. World Politics. 59: 440-475. 
Hunter, Wendy, and Timothy J. Power. Rewarding Lula: Executive Power, Social Policy, and the Brazilian Elections of 2006. Latin American Politics and Society, 49 (1): 130.

Ibarz, Joaquim. 2005. El PRD ya no existe. La Vanguardia, Barcelona, Jan. 13, 2005.

"Iginio". Asamblea de Barrios member. Author interview. Mexico City, Sept. 23, 2004.

Instituto de Formación Política del Partido de la Revolución Democrática. 2004.

Transcripts of meetings and notes of proposals leading up to the party's eighth National Congress in March, 2004. Mexico City.

"Isabel”. Social Housing Organization member. Author interview. Mexico City, Dec. 7, 2004.

Juárez Vázquez, Luz María. Federal District Health Ministry Coordinator for Senior Citizens’ Programs. Author interview. Mexico City, Dec. 2, 2004.

Keck, Margaret E. 1992. The Workers' Party and Democratization in Brazil. New Haven and London: Yale University Press.

Kitschelt, Herbert. 2000. Linkages Between Citizens and Politicians in Democratic Polities. Comparative Political Studies. 33 (6/7): 845-79.

Kitschelt, Herbert, and Steven J. Wilkinson. 2007. Patrons, Clients, and Policies: Patterns of Democratic Accountability and Political Competition. New York: Cambridge University Press.

Kurer, Oskar. 1993. Clientelism, corruption, and the allocation of resources. Public Choice. 77: 259-73. 
Legg, Keith R. 1975. Patrons, Clients, and Politicians: New Perspectives on Political Clientelism. Working Papers on Development: 3. Berkeley: University of California, Institute of International Studies.

"Luisa". Frente Popular Francisco Villa member. Author interview. Mexico City, Dec. 8, 2004.

Martínez González, Víctor Hugo. 2003. Fisiones y Fusiones, Divorcios y Reconciliaciones: La dirigencia del Partido de la Revolución Democrática (PRD) 1989-2002. Dissertation, Facultad Latinoamericana de Ciencias Sociales Sede Académica de México.

Meyenberg, Yolanda, and Ulises Carrillo. 1999. El Partido de la Revolución Democrática. Avances electorales, responsabilidad de gobierno y ambigüedad identitaria. Revista Mexicana de Sociología. 61 (3): 53-68.

Middlebrook, Kevin J. 1995. The Paradox of Revolution: Labor, the State, and Authoritarianism in Mexico. Baltimore: Johns Hopkins University Press.

Muñoz Ledo, Porfirio. 2000. Sumario de una izquierda republicana. México, D.F.: Oceano.

Nylen, William R. 2003. Participatory Democracy vs. Elitist Democracy: Lessons from Brazil. New York: Palgrave Macmillan.

Oliveira, Francisco de. 2005. Radiografía da Política. Reprinted from Jornal Brasil de Fato, July 11, 2005, www.mst.org.br. Accessed Dec. 10, 2007. .2006. Lula in the Labyrinth. New Left Review. 42. www.Newleftreview.org. Accessed Dec. 10, 2007. Ortega, Jésus. Senator, PRD. Author interview. Mexico City, Nov. 9, 2004. 
Panebianco, Angelo. 1988. Political parties: organization and power. Cambridge:

Cambridge University Press.

Partido de la Revolución Democrática. 1993. Estatutos (Contiene las reformas aprobadas en el II Congreso Nacional del Partido realizado del 15 al 18 de julio de 1993). México, D.F.: Propuesta Democrática. . 2004. Nuevo Estatuto Aprobado en el VII Congreso Nacional del PRD. México, D.F.: PRD.

Piattoni, Simona. 2001. Clientelism in Historical and Comparative Perspective. In Clientelism, Interests, and Democratic Representation: The European Experience in Historical and Comparative Perspective, ed. Piattoni. Cambridge: Cambridge University Press. 1-30.

Pierson, Paul. 2000. Increasing Returns, Path Dependence, and the Study of Politics. American Political Science Review. 94 (2): 251-267.

Powell, John Duncan. 1977. Peasant Society and Clientelist Politics. In Friends, Followers, and Factions: A Reader in Political Clientelism, ed. Schmidt, Scott, Landé, and Guasti. Berkeley: University of California Press. 147-161.

Prud'homme, Jean François. 1996. Party Strategies and Negotiations over the Rules for Electoral Competition: Mexico (1988-1994). Ph.D. Dissertation, York University. Putnam, Robert D. 1993. Making Democracy Work: Civic Traditions in Modern Italy. Princeton: Princeton University Press.

Reding, Andrew. 1997. Aztec Sun Rising: The Cárdenas Challenge. World Policy Journal. 14: 63-70. 
Remmer, Karen L. 2007. The Political Economy of Patronage: Expenditure Patterns in the Argentine Provinces, 1983-2003. The Journal of Politics. 69(2): 363-377.

Ricci, Paolo. 2003. O Conteúdo da Produção Legislativa Brasileira: Leis Nacionais ou Políticas Paroquiais? DADOS - Revista de Ciências Sociais. 46(4): 699-734.

Roniger, Luis. 1990. Hierarchy and Trust in Modern Mexico and Brazil. New York: Praeger.

Samuels, David. 2004. From Socialism to Social Democracy: Party Organization and the Transformation of the Workers' Party in Brazil. Comparative Political Studies. 37(9): 999-1024.

Sánchez, Marco Aurelio. 1999. La Élite en Crisis: Problemas Organizativos, Indeterminación Ideológica y Deficiencias Programáticas. México D.F.: Plaza y Valdés.

2001. PRD: El Rostro y la Máscara. Reporte de la Crisis Terminal de una Élite Política. México, D.F.: Centro de Estudios de Política Comparada y Centro de Estudios para la Transición Democrática.

Sartori, Giovanni. 1976. Parties and Party Systems. New York: Cambridge University Press.

Schaffer, Frederic C. 2007. Why Study Vote Buying? In Elections for Sale: The Causes and Consequences of Vote Buying, ed. Schaffer. Boulder: Lynne Rienner. 1-16.

Schmitter, Philippe C. 1974. Still the Century of Corporatism? The Review of Politics. 36 (1): $85-131$. 
Selee, Andrew D. 2006. The Paradox of Local Empowerment: Decentralization and Democratic Governance in Mexico. Ph.D. Dissertation, Maryland School of Public Policy.

Semo, Enrique. 2003. La Búsqueda. 1. La izquierda mexicana en los albores del siglo XXI. México, D.F.: Oceano.

Singelmann, Peter. 1981. Structures of Domination and Peasant Movements in Latin America. Columbia: University of Missouri Press.

Teichman, Judith A. 2001. The Politics of Freeing Markets in Latin America: Chile, Argentina, and Mexico. Chapel Hill: University of North Carolina Press.

Tejera Gaona, Héctor. 2003. “No se olvide de nosotros cuando esté allá arriba.” Cultura, Ciudadanos y Campañas Políticas en la Ciudad de México. México, D.F.:

Universidad Autónoma Metropolitana, Universidad Iberoamericana, Miguel Ángel Porrúa.

Trelles, Alejandro, and Héctor Zagal. 2004. AMLO: Historia política y personal del jefe de gobierno del D.F. Mexico: Plaza Janés

Valdés, Leonardo. 1994. Partido de la Revolución Democrática: The Third Option in Mexico. In Party Politics in 'An Uncommon Democracy'. Political Parties and Elections in Mexico, eds., Neil Harvey and Mónica Serrano. London: Institute of Latin American Studies. 61-75.

Wainwright, Hilary. 2005. Corruption of Hope in Brazil. The Nation, Nov. 14, 2005

Ward, Peter M., and Elizabeth Durden. 2002. Government and Democracy in Mexico’s Federal District, 1997-2001: Cárdenas, the PRD and the Curate's Egg. Bulletin of Latin American Research. 21 (1): 1-39. 
World Bank. 2006. Mexico Country Brief. www.worldbank.org. Accessed July 20, 2007.

World Bank. 2007. Brazil Country Brief. www.worldbank.org. Accessed Jan. 25, 2008.

\footnotetext{
${ }^{\mathrm{i}}$ A previous version of this article was presented at the 2007 meeting of the Latin American Studies Association in Montreal. I would like to thank Judith Adler Hellman, Philip Oxhorn, Peter Singelmann, Steve Hellman, Bob MacDermid, Judith Teichman, Eduardo Canel, Simone Bohn and three anonymous reviewers for their comments. Funding for this research was provided by the Fonds québécois de recherche sur la société et la culture, the Social Sciences and Humanities Research Council of Canada and York University. Institutional support was provided by the Colegio de Mexico and the Centre for Developing-Area Studies at McGill University.

${ }^{\text {ii }}$ To be sure, societal, or neo-, corporatism has been a prominent feature of a number of Western European social democracies. Here, business, labour, and the state engage in tripartite negotiations to determine policy orientations. Perredistas have, however, been more influenced by the PRI's state corporatism, where the corporatist sectors are used to carry out the state's will. See Schmitter 1974.

${ }^{\text {iii }}$ For an analysis of the difficulties in relationships between social organizations and the PRD, see Bruhn 1997a and 2003.

${ }^{\text {iv }}$ I am grateful to an anonymous reviewer for drawing my attention to this case.

v The cases are from fieldwork done in Mexico City from August to December 2004. I use the real names of large, well-known organizations, but omit the names of smaller groups and have changed the names of all individuals in order to protect their identity.
} 